\title{
The Exploration about English Teaching Methods toward Arts and P.E. Majors in Colleges and Universities
}

\author{
Shuang WANG \\ ${ }^{1}$ School of Foreign Languages, Linyi University, Linyi, Shandong, China \\ awangsh1215@163.com
}

Keywords: Arts and P.E. Majors, Problems, English Teaching Methods.

\begin{abstract}
There are several common problems in English learning of the arts and P.E. students, such as their low-proficiency in English, unwillingness to learn, and even fear or dislike of English learning. But many of the problems have not drawn enough attention of teachers, as well as the society. As a public English teacher in university, the author has been teaching the students of arts and P.E. for several years and puts forward some ideas of dealing with the problems in this paper.
\end{abstract}

\section{Present Situation of Teaching}

With the expansion of enrollment for colleges and universities, the number of arts and P.E. students shows the tendency of increase gradually. However, what is the situation of their studying after they enter the colleges or universities? According to the author's visit and questionnaire, the English learning in China has the following characteristics.

\section{Before Entering College}

In China, the college admission is given priority to professional class scores, with academic grades significantly lower than other professional ones. This is probably the result of division in high schools which divides students to liberal, science or arts classes in their second year of high school learning. The students who can get higher score in exam, will choose liberal and science, while the others have to learn arts or P.E. Only in that way, will it be possible that more students can pass the university entrance exam. [1]Students in arts and P.E must invest most of their time on the training of professional skills, and therefore, naturally, English and other academic subjects can't get their attention to some degree. As a result, the students almost stay in the primary stage of learning English.

\section{After Entering College}

When entering the university English learning, students feel great difficulty because of their rare vocabulary accumulation and lack of grammar. So they could not fit in English learning in college, what's more, they will gradually lose interest in English, and then lose their learning enthusiasm, which lead to the failure of English learning[2].

\section{Teaching Countermeasures}

How can we adjust the teaching methods to solve the problems, not only improve English teaching effect and change their state of learning. The followings are what we can try.

\section{The Harmonious Relationship between Teachers and Students}

In language teaching, the interaction between teachers and students is saturated with the touch of the soul, as a education workers, we should be concerned with the life and health of the young students; we need to care about their future and employment, focus on their inner world, instead of isolating the relationship between teachers and students with only teaching knowledge at class. Of course, our education must comprise the input of noble spiritual value and wisdom as well as academic thinking. With lack of harmony, the friendship between teachers and students will become a vulgar intimate 
relationship, which only does harm to teaching. What makes it worse is that we will lose the ultimate goal of education, which is to discover and explore people's interest inside their hearts.

\section{Stimulate Learning Interest}

According to the principle of psychology, non-intelligence factors and personality factors have a huge impact on English learning and practice. Non-intelligence factors including motivation, interest, emotion, will, personality, etc[3]. Our educational instructors should make full development and utilization of the student's non-intellectual factors to help them learn English well. People's potential is infinite; a strong faith in their hearts will lead people to the kind of life they want. If you tell yourself you can do something well, the brain will receive a signal to stimulate you. When you believe something is destined, the faith can give yourself a successful subconsciousness. Teachers should tell students not to underestimate the power of faith in learning English well, and they can create miracles if they firmly believe in themselves. So during teaching, teachers must be careful to deepen their feeling of failure in learning English, and try their best to let students experience the joy of success [4]. As a result, teachers must praise as soon as students make a little progress in English learning, and make sure they can enjoy their success, in order to form a successful mind-set. Therefore, their mind will be filled with a feeling of profound self-affirmation, which can arouse their learning interest, and interest will bring them more power of learning. A lasting power of learning comes giving students the sense of achievement from time to time.

\section{Develop Correct Learning Methods and Habits}

Students should integrate English into daily life, for instance, they can read English magazine, novel, news and other literatures to increase vocabulary. All their reading will become their intellectual background, and the richer the background is, the easier their learning will be [5]. During the reading time, we suggest students read loudly. This is a training that can "kill two birds with one stone", which not only improves the concentration and fluency of reading, but also improve their reading comprehension. Students should attach importance to reading skills, focus on reading contents, rather than the reading process. We also recommend students read in thinking, and to read such a degree of automation, the vision and consciousness ability to sense the reading materials. After training, you should be able to can grasp the meaning of long sentences with a glance at it.

\section{Improving Teaching Methods}

Concerning the week grammar and lack of vocabulary in arts and P.E. students, teachers should try their best to help them catch up. In the teaching of vocabulary, the teacher needs to make their instruction more lively and interesting and never isolate words learning from sentences and texts. We can adopt concentrated dispersion, and alternate complement each other. Arts and P.E. students usually have strong performing desire. According to this, in the classroom teaching, the teacher are encouraged to put students as the center, with a variety of teaching methods to create a relaxing and lively, classroom atmosphere[6]. Pay attention to the interest and experience of student; let them learn English happily and have a sense of achievement. Through watching movies, learning English songs, making dialogues and role plays, students can be more stimulated in English learning. Teachers should also create opportunities for students to apply what they have learned the language for self-expression, and prepare a lesson with the students' real concern, design some activities which is parallel to daily life to increase their willingness to participate in class. Games are also necessary and effective, teachers can design games to improve the interest of learning English. Students can play different role in drama to practice their speaking [7]. In this way, we can promote the oral communication and practice their writing skill step and step.

\section{Summary}

Arts and P.E. students are different from the ordinary undergraduate students, their English will be directly related to the influence in the world of our country. Teachers should combine the characteristics 
of the special students, conscientiously implement suitable teaching methods in their teaching based on the students' aptitude. At the same time, English teachers should pay attention to lift themselves. Through a variety of teaching activities and flexible teaching methods, teachers will cultivate qualified talents to meet the requirements of the fast developing society.

\section{References}

[1] Lee, W. (1957). The Linguistic Context of Language Learning. English Teaching Journal, (11): $77-85$

[2] Cui Haiyong. (2012). Error Analysis of College Students' Lexical and Syntactic Features. MA thesis. Changchun: English Composition: Jilin University.

[3] Ferris, D, \&Tagg, T. 1996. Academic listening/speaking tasks for ESL students: Problems suggestions and implications. TESOL Quarterly, 30(2): 297-320.

[4] Jackson, J.2003. Case-based Learning and Reticence in a Bilingual Context: Perceptions of Business Students in Hong Kong. System, 31:457-469.

[5] Tan, Z. 2008. 'Questioning in Chinese university EFL classrooms: what lies behind it?' Regional Language Centre Journal, 38(1): 87-103.

[6] Wang, Q. 2006. A course in language teaching (2nd ed.). Beijing: Higher Education Press.

[7] Zhang, X. Q.,\&Katie, ELT Journal, 64(1): H. 2010. Dealing with learner reticence in the speaking class. 